\title{
Model of Community Learning Center Management in Improving Education Service
}

\author{
${ }^{1}$ ASEP SAEPUDIN, ${ }^{2}$ EKO SULISTIONO, ${ }^{3}$ ANI RINDIANI \\ 1,2Department of Community Education, Faculty of Education Sciences, Universitas Pendidikan \\ Indonesia (UPI), Dr. Setiabudhi Street No. 229 Bandung, Indonesia. \\ ${ }^{3}$ Islamic Education Management, Postgraduate at UIN Sunan Gunung Djati Bandung, Indonesia, \\ Cimencrang Street, Gede Bage, Bandung, Indonesia \\ Email: ${ }^{1}$ aspudin@upi.edu; ${ }^{2}$ ekosulistiono@upi.edu; ${ }^{3}$ ani.rindiani288@gmail.com
}

\begin{abstract}
The purpose of the research is to validate the model design of Community Learning Center (CLC) management in improving education services. This research uses a qualitative approach with a descriptive method. The results show that first, the conceptual model consists of rationalization, assumptions, objectives, components, indicators, and model procedures; second, validation of model is conducted through discussions with peer groups and expert judgment; third, implementation of model trials is described in learning activities in CLC. The learning steps include the process of planning, organizing, implementing and assessing in learning. The conclusions of the developed model show effective results with indicators: first, there are active involvements and positive responses of community members to the learning activities; second, learning outcomes of community members show there is an increase in the ability of knowledge, attitudes and skills.
\end{abstract}

Keywords: validation, management, non-formal education

\section{Introduction}

The development of science and technology has led to accelerated changes in all fields that affect human life. Responding to changes in the development of an increasingly globalized world, UNESCO (Saepudin, 2019) applies four learning pillars: learning to know, learning to do, learning to live together, and learning to be. Learning to know contains the meaning of how to learn, learning to do contains dimensions of human life skills, learning to live together contains dimensions of multicultural life, and learning to contain the meaning of learning to recognize identity, abilities, weaknesses and competencies that are mastered in building a whole life sustainably.

The application of the UNESCO's four pillars of learning (2005) created the concept of a learning revolution. Modern learning models are training students to become learning resources, changing passive learning models to active learning models, changing factual thinking models to critical thinking models, from less active responding to proactive in responding, from abstract thinking to authentic thinking. This change places the role of non-formal education in a strategic position. National Education System Law No. 20 of 2003, article 26, paragraph 1 , explains that: "Non-formal education is held for citizens who need education with the function as a substitute, addition, and/ or complement to the formal education in a series of supporting lifelong education".

The concept of non-formal education as one of the sub-systems of national education has a very broad and complex scope. Theoretically, Saepudin (2015) defines non-formal education as an organized and systematic activity, carried out outside the established school system, carried out independently or is an important

Received: September 12, 2020, Revision: April 01, 2021, Accepted: June 28, 2021

Print ISSN: 0215-8175; Online ISSN: 2303-2499. DOI: https://doi.org/10.29313/mimbar.v37i1.6653

Accredited Sinta 2 based on the decree No.10/E/KPT/2019 until 2024. Indexed by DOAJ, Sinta, Garuda, Crossreff, Dimensions 
part of wider activities that are deliberately conducted to serve certain students in the school to achieve their learning goals. Community Learning Center (CLC) is one of the non-formal education units that have a strategic position in providing education to educate and empower the community.

Based on the logical line above, the implementation of learning programs in CLC is an educational approach on nonformal education pathways based on the convergence of learning needs with learning resources in the community that forms a learning system. In his study, Saepudin (2017) explained that CLC is a non-formal education unit that organizes various learning activities according to the needs of the community on the basis of ideas from, by and for the community. As a learning system, CLC is built on the following five components:

(1) learning needs, (2) learning resources, (3) learning programs, (4) learning groups/ learning platforms, and (5) facilitator of learning activity. The concept of CLC as an out-of-school education unit emerged in the early 1990s, which was popularized through a meeting of world leaders. In his study, Ardiwinata (2014) explained that in the world declaration in 1990 on Education For All (EFA) in Jomtien, Thailand, there were almost 155 countries that initiated the Community Learning Center (CLC) as the forerunner to the emergence of the term "Pusat Kegiatan Belajar Masyarakat (PKBM)" in Indonesia. Sihombing and Gutama in the study of Saepudin (2019) stated that the Community Learning Activity Center is an educational unit developed and managed by the community and held outside the formal education system. For this reason, CLC acts as a place for community learning of various knowledge or skills by utilizing existing facilities, infrastructure and potentials around their environment (villages or cities) so that the community have skills that can be used to improve the living standards and learning achievements of the community. This is reinforced by the results of research conducted by Irmawati (2017) which states that CLC has proven to be very instrumental in reducing illiteracy in Karimun Regency.

The important objectives in developing CLC according to Zainal (2019) are first, facilitate various learning needs of the community with a variety of problems; second, to prepare, improve and develop human resources in order to have the knowledge, skills, attitudes and competitiveness to obtain future opportunities. Sihombing (2019) stated that the purpose of institutionalizing CLC is to explore, grow, develop, and utilize all the potential that exists in the community itself. In the meaning that it aims to empower all potentials and educational facilities in the village as an effort to educate the community which is directed to support poverty alleviation with the principle of development in order to realize democracy in the education. In addition, in its implementation, CLC must start from meaning and usefulness (Irwan, 2016).

The terms related to CLC: center means centralization of management, not in the sense of centralizing various CLC service programs in one place. Centralized management of CLC implementation is especially meaningful in terms of problem solving and resource utilization. Learning activities mean that every CLC service program or activity is held in a learning setting so that the process and results of programs and service activities that are followed and obtained by the program target residents must have an impact on changes in knowledge, attitudes and skills. The community is the main target and ultimate goal of any program or service activity designed by CLC. On the other hand, the community is also the main target and final target of facilitation and assistance carried out by outside parties. According to Hikmat (Saepudin, 2019), facilitation and or assistance from outside the community and community involvement in CLC implementation is oriented to strengthening the ability of the community to play an active role: (1) as organizers of efforts to fulfill their learning needs; (2) in every decision-making process concerning efforts to improve the standard of living; and (3) as the initiator and motivator for the community itself and other communities in the surrounding environment. In this regard, the achieving community is a society that is willing to learn. Based on the opinion above, Septiani (2015) explained that some of the tasks of CLC include (a) identifying and addressing community needs; (b) meeting community needs and interests through various activities; (c) mobilizing resources in the community; (d) building close cooperative relationships and partnerships with other organizations and institutions; (e) monitoring and reviewing the progress to assist in future planning; and $(f)$ documenting the strengths and weaknesses of CLC activities. 
Considering the characteristics and trends of non-formal education problems that currently lead to addressing the real needs of the community, the orientation of CLC program as a non-formal education unit is projected on community education with a Community Based Education (CBE) approach. According to Fasli Jalal and Dedi Supriadi (Saepudin, 2019) Community Based Education emphasizes the importance of understanding the community, its characteristics, needs, weaknesses and strengths. In its implementation, $\mathrm{CBE}$ is a method that emphasizes how to solve problems by the community by utilizing the potential of the environment (to help people, to help themselves). Community Based Education is developed based on several conceptions as follows: lifelong education, critical education that emphasizes on improving the basic abilities of the community, increasing existing abilities, and participation in every activity, Andragogy, and Learning organization.

The accuracy of CLC to organize community-based education is reinforced by Lubis's (2018) thinking that education is a social process, therefore education in a society must be different from other communities; it should be in accordance with the character of the community itself.

Based on empirical data, the characteristics of education organized by CLC in Bandung area have been proven to be able to improve the quality of human resources. The education programs organized by CLC are generally equivalence education programs of package $A$, package $B$, and package $C$, early childhood education programs, life skills education programs (skills courses), and other community education organized according to the needs and potential of the surrounding community. However, on average, CLC in Bandung area has not yet fully implemented education according to National Education Standards. This is due to the fact that CLC has not yet fully qualified in terms of implementation management, standardization and administrative order, and the physical feasibility of the institution as an education provider.

On the other hand, efforts to develop national education through both formal and non-formal education continue to be continuously improved as an implementation of the government's commitment to provide the quality education as mandated in the
Preamble of 1945 Constitution, as well as the National Education System Law no. 20 of 2003. The policy on optimizing nonformal education is also strengthened by Government Regulation No. 73 of 1991 on out-of-school education. Therefore, it is very reasonable if CLC as one of the nonformal education units gets more attention and continues to be strengthened as an educational institution that has been proven to be able to empower the community through various educational programs according to the needs of the community.

Based on the thought above, the purpose of this research is to validate the model for strengthening CLC management in Bandung area. The great hope for the benefits of this research is to be able to empirically reveal the variety of CLC management, the minimum standards for CLC implementation, and efforts to formulate a conceptual design for quality CLC services needed by the community, especially in Bandung area.

\section{Research Methodology}

This research uses a qualitative approach with a descriptive method. In relation to qualitative research, it is a method used to examine the condition of natural objects (Sugiyono, 2017). The research subjects used as the main data sources are CLC management elements and elements of the Education Office in Bandung area (Bandung City, Bandung Regency, and Bandung Barat Regency). Each region is represented by four CLC. In each Regency/ City, it is taken a sample of 1 (one) determined CLC. In order for this research to be focused and carried out in depth, the number of research subjects/informants is limited with the consideration that these informants have the information needed by the researchers. In this case, the researchers use purposive sampling in their sampling technique. As mentioned by Kisworo (2017), purposive sampling is sampling based on research choices about who and what aspects are focused on in current and certain situations continuously throughout the research. Sampling is purposive, that is, it depends on the purpose of the focus.

Thus, from each CLC unit, it is determined that there is one manager, one learning resource element/instructor, and two community members as students. Therefore, the number of primary research informants is 
12 people: 3 managers, 3 learning resource elements, and 6 community members.

The research aspects explored from the research subjects are (1) the design of the institutional management model, (2) the description of the model validation, and (3) the implementation of the management strengthening model. The data collection technique used is observation, interviews, documentation, and questionnaires. Furthermore, data analysis is conducted in several stages as revealed by Sugiyono (2017): (1) data collection, (2) data reduction, (3) data presentation, and (4) conclusion and verification.

\section{Results and Discussion}

\section{Design of CLC Management Strengthening Model in Bandung Area}

The conceptual model that will be validated is the model of the research conducted by the author at the model design development stage. This model consists of rationalization, assumptions, objectives, components, indicators, and model procedures. The six aspects are described as follows: first, rationalization of model development is based on the idea that CLC is an out-of-school education unit that has a very important role in education in the community, especially in Bandung area. This is evident from: (1) the public's interest in attending education at CLC institutions is very high, (2) CLC has succeeded in becoming an alternative educational institution, such as becoming a substitute and complement to formal education, which is very effective. On the other hand, CLC education unit in its development faces various obstacles related to the performance of the programs carried out in it, including the quality of service and the availability of infrastructure. Thus, the quality standards of CLC in various regions need to be improved. For an increase in productivity and the fulfillment of the quality of CLC services, it is necessary to organize the quality and management of CLC, especially in Bandung area through the intervention of implementing a model of strengthening management in improving the quality of education services for the community.

Second, CLC management model development assumptions has potential and opportunities that can be developed in CLC management, but on the other hand, it is faced with various obstacles (problems) in developing CLC, namely limited facilities and CLC development capabilities. For this reason, the CLC manager is expected to have management competence in carrying out discovery activities, especially with regard to the ability and skills to solve the problems encountered and try to correct the deficiencies experienced.

Third, the purpose of developing this model is to offer a model for strengthening CLC management for managers in improving the quality of education services to the community, which is oriented towards strengthening the competence of planning, implementing, and evaluating programs.

Fourth, the components of the model are related to management principles which were developed by considering: (1) targets, (2) learning materials, and (3) learning resources. To develop the model, a set of instruments was designed that complements the model, namely (1) instruments in the exploratory process in identifying the needs of model construction as the main basis for formulating model designs, and (2) instruments for model implementation processes. While the elements of the model program consist of: (1) planning, (2) organizing, (3) implementation, and (4) assessment.

Fifth, the model indicators include (1) growing awareness for CLC managers; (2) there is active involvement between education program managers, educators and students (learning residents) who jointly plan, organize, implement and evaluate learning activities according to problems and needs of learning; (3) improving the quality of education services in CLC units according to national education standards.

Sixth, the trial procedure for
implementing CLC management strengthening model is carried out through four stages of activity such as introduction, development, evaluation, and dissemination. The procedure is visualized as follows Figure 1.

The design of CLC strengthening model compiled in this study is according to principles of CLC development. According to Sihombing (2019), some basic principles that can be used as a reference in developing and compiling CLC program are a) the program developed by CLC must be broad so that learning citizens have broad opportunities to develop experiences about knowledge, 


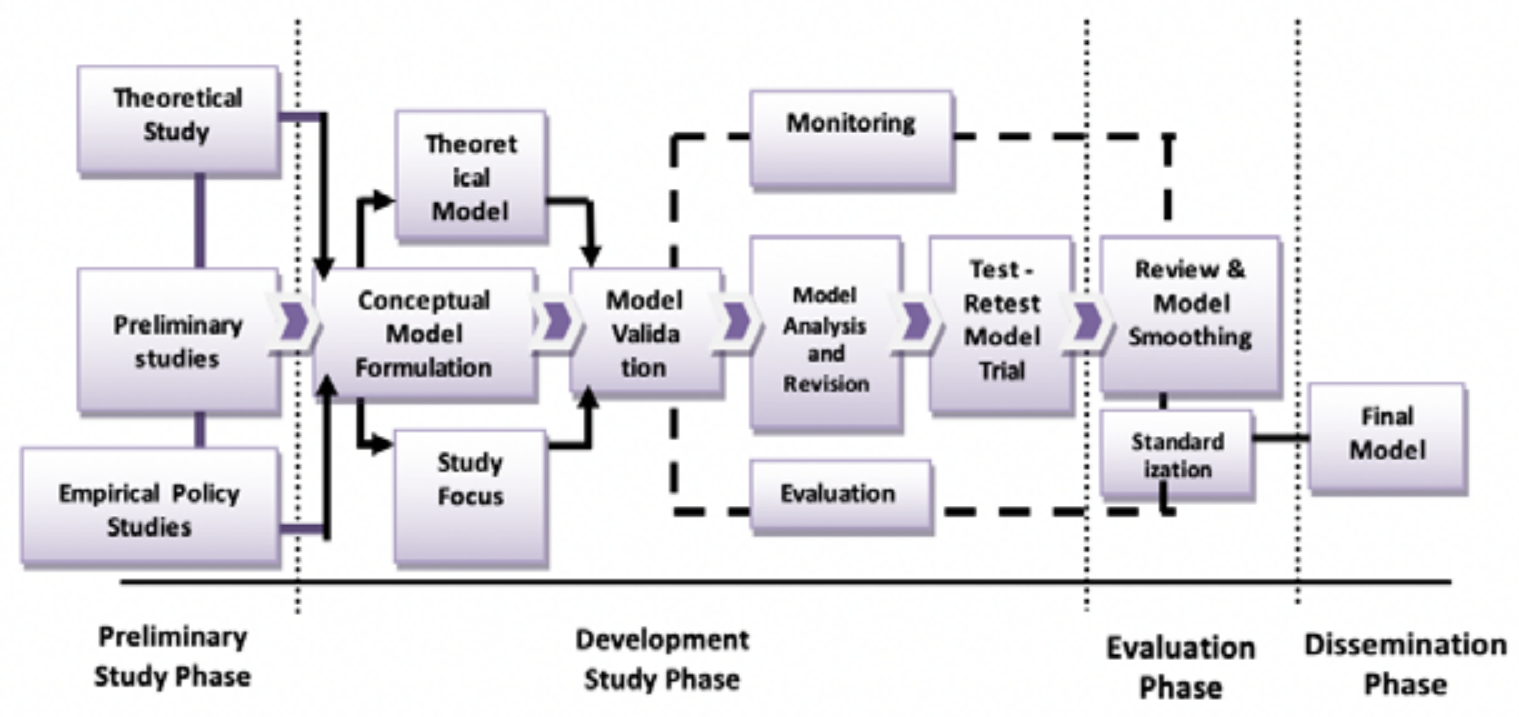

Figure 1. Model Development Flow

skills, attitudes and values related to ethics, aesthetics, logic and kinesthetics during learning; b) the program must have a balanced principle where every competency developed in the CLC program must be achieved through sufficient time allocation for an effective learning process; $c$ ) the program developed by CLC must be relevant because every program is related to the preparation of learning community to improve the quality of life through opportunities, experience, and training in playing a responsible role and attitude in realizing maturity of thought; d) programs developed by CLC must be able to put forward the concept of difference, the principle of an individual service effort where learning citizens must understand what needs to be learned, how to think, how to learn, and act to develop their potential and needs optimally.

In an effort to implement the principles of CLC or PKBM so that it is in line with the interests and abilities of the community, it is necessary to develop a minimum standard of community-based PKBM management. The objectives of developing a minimum standard of PKBM Standards and PKBM Implementation Procedures (Depdikbud, 2015) are (a) PKBM that has been formed can harmonize and adjust its implementation process with all the potential and resources around it and at the same time provide insight into the interests of wider development; (b) it can be used as a tool for facilitating government officials in the formation of PKBM by the community.

Another thing that strengthens the design is the fulfillment of the minimum standard scope of CLC which is measured based on 8 (eight) National Education Standards as stated in Government Regulation no. 13 of 2015 , on the amendment of PP No. 19 of 2005. The eight aspects are (1) content standard, (2) process standard, (3) graduate standard, (4) educator standard, (5) infrastructure standard, (6) management standard, (7) assessment standard, and (8) finance standards. So far, the development of National Education Standards as well as monitoring and reporting on their achievements nationally has been conducted by a standardization, assurance and quality control agency for education (Triwiyanto, 2013). The agency that handles the standardization and quality feasibility is the National Accreditation Board (BAN), including BAN PAUD (early childhood education) and PNF (non-formal education). In her study, Asiah (2018) explained that PAUD and PNF accreditation measures the scope of PAUD and PNF unit management which includes what is managed, how to plan it, and where the education unit management will be directed to.

\section{Validation of CLC Management Strengthening Model in Bandung Area}

In an effort to produce an effective CLC management strengthening model, a feasibility test of the conceptualized model (hypothetical model) is conducted before it is implemented. The model feasibility test is conducted in two stages: the model quality analysis stage and the expert judgment 
stage. First, the model analysis stage is carried out by examining the content and the relationship with each aspect of the model. Analysis of the model is conducted by researchers and discussed with peers (peer group). This model analysis activity is conducted systematically to see the feasibility of CLC management strengthening model as a unified whole, interconnected from one aspect to others. The final goal at this stage is not only to see whether the content of the model is adequate but also to find out whether the relationships between the aspects developed are appropriate.

Second, the expert judgment stage is conducted by consulting with education curriculum experts, communication experts, and CLC practitioners. The experts involved in the model assessment are those who have educational backgrounds that are relevant to the needs of developing CLC management strengthening models. The expert assessment process is carried out using a detailed response technique where the researcher conveys the concept of CLC management strengthening model along with an integrated instrument in a format to the experts who have been assigned. The experts then just fill in their opinion in the column that has been provided in the fill format.

In relation to the validation of the model recommended by experts, the structure of the model has been dealt with the minimum standards for CLC implementation as stated in CLC Implementation Standard and Procedure Book issued by the Ministry of National Education (2015), which is physical standards (facilities and infrastructure), including first, the minimum management standard which describes the minimum activities that need to be conducted by CLC manager so that CLC function can run. The management activities are described based on the stages of planning, organizing, implementing, controlling, and evaluating. Second, the minimum standard of physical facilities describes the minimum supporting facilities and infrastructure that need to be prepared by the manager to be used in the management of CLC activities.

In addition, referring to the validation results, information is obtained that the main functions of CLC have been fulfilled. There are at least four areas of activity that can be managed by CLC manager: first, education includes mentoring or counseling activities, teaching and training; second, information services include the following activities: (1) collecting information from CLC, the surrounding community, and outside institutions, (2) providing information services to the surrounding community and outside institutions; third, information networks and partnerships include activities: (1) developing information networks and partnerships with existing institutions inside and outside the community in organizing activities in CLC and partner institutions, (2) maintaining the established network; and fourth, the development of CLC educational staff includes activities to improve the quality of performance of management staff and educators (tutors, speakers) both independently and with external facilitation. Another function of CLC is expressed by Cenny (2018) who stated that CLC functions as a place to explore, study, and analyze various problems in the field of non-formal education.

Based on the explanation above, the design and implementation of CLC as a forum for improving all levels of community members through non-formal education channels is expected to meet expectations as part of community-based education due to inadequate supporting factors and internal capabilities. CLC conditions as described above are increasingly worthy of being called non-formal education units as alternative education for anyone who needs additional education and skills (Suryadi, 2020). The feasibility of the validation results above has met the requirements because it is followed by the validation data as disclosed by Kurnianto (2019) that model validation needs to be done by providing empirical evidence.

\section{Implementation of CLC Management Strengthening Model Trial in Bandung Area}

The implementation of the model is described in learning management activities in CLC. Conceptually, management is defined by Dewi (2014) as activities that is performed together and through people and groups with the aim of achieving organizational goals. The steps of learning management as a component of the model are the process of planning, organizing, implementing and evaluating in learning.

The planning stage is the initial activity 
conducted by the manager before applying all learning activities. Therefore, at this stage, CLC managers should perform learning planning carefully and systematically. Learning planning in its implementation involves many parties, especially those who are related to the needs and impacts of implementing this model. Planning activities are conducted through four activities: general identification of learning needs, determination of learning needs based on the largest portion, identification of learning resources, and identification of cooperation partners. The results of the study are in the same opinion with the thoughts from Irmavita (2018) that the planning steps include the following activities: first, determine program objectives; second, determine the material or learning materials and their organization; third, determine the strategy for implementing the program of activities; and fourth, determine how to assess the results of the program/activity.

This organizing stage is directed to formulate: first; learning planning is related to: (a) learning objectives that are tailored to the general goal of increasing the knowledge and skills of community members in improving their abilities; (b) learning materials directed at materials that can increase knowledge and skills in improving community self-efficacy; (c) learning methods and techniques that are adapted to the type of material being studied, whether it requires lecture, discussion, assignment or simulation techniques; (d) learning media/ tools that are adapted to the material to be studied.

The implementation stage is a learning activity that is directed in an interactive, democratic and participatory atmosphere or climate of activities in the form of learning and training. Learning resources that have broad opportunities to become managers so that there is a transfer of knowledge and skills from them or other parties to the community as students in these learning activities. Either alone or involving other parties, mentors or learning resources perform activities aimed at assisting or accompanying the community learning process. Learning resources strive to improve the knowledge and skills of the community in increasing their abilities according to their needs.

The evaluation stage is performed to observe several aspects that are a measure of learning outcomes conducted by community members as learning citizens or students. The results obtained showed an increase in the average score of the pre-test and post-test of the students. In addition, the evaluation of the manager shows relatively good response and assessment of the students.

Based on the description above, the implementation of CLC management strengthening model is considered to increase the competence of community members so that they have skills in solving problems they face in their lives. Improving the skills of learning citizens can be conducted by CLC managers through training for their students. Training is a planned effort to facilitate learning about work related to the knowledge, skills and behavior of employees (Nurleni, 2018).

Knowledge, skills and behavior are competencies described by Hasanati (2017) as the abilities to carry out tasks, assignments or roles, which are obtained from experience and learning through work.

Accordingly, the competencies achieved by the community is in the form of abilities based on knowledge, skills, and also supported by the attitude required in performing their work duties. This means that only people who are willing to learn will have the competence. One of the means of increasing competence that is relevant to the needs of the community is through learning at CLC education unit. This is according to the research results from Firmansyah (2012) that the learning process in CLC contributes $76 \%$ to the mastery of knowledge of the learning citizens. The capable community is social capital. In this context, social capital in education plays an important role in building social skills (Sumarni, 2015). For this reason, social skills need to be trained properly, as expressed by Nurleni (2018) that training is a planned effort to facilitate learning. The same thing was expressed by Untadiyah (2021) that training is a learning process that involves the acquisition of skills, concepts, rules, or attitudes to improve human performance.

The flow of the description above shows that the implementation of CLC strengthening model can produce competent quality graduates as social capital, which in turn is very dependent on the quality of CLC management. The results of a study from Hardjono (2019) reveal that there are three things that can determine the quality of CLC 
management implementation: input quality, process quality, and output quality.

Evaluation is the end of learning management activities in the implementation of the model. Based on the results of the research above, conceptually, evaluation activities have been performed properly and systematically as expressed by Agustanico (2017) that evaluation is a tool or procedure used to find out and measure something in an atmosphere with ways and rules that have been established and determined.

\section{Conclusion}

The conclusions of this research results are as follows: first, the conceptual model developed consists of rationalization, assumptions, objectives, components, indicators, and model procedures; second, model validation is performed using two methods: discussion with peers (peer group) and expert judgment; third, the implementation of model trials is described in learning activities in CLC.

The learning steps as a component of the model are the process of planning, organizing, implementing and assessing in the learning. The conclusion of the developed model shows effective results with the following indicators: first, there is active involvement and positive response of community members to the learning activities; second, the learning outcomes of the community members showed that there is an increase in the ability of knowledge, attitudes and skills.

\section{Acknowledgment}

Our gratitude goes to the Ministry of Education and Culture, the Director General of Higher Education of the Republic of Indonesia who has provided research funding support, LPPM of Indonesia University of Education (UPI) which has facilitated research, the Chancellor of UPI and the Dean of the Faculty of Education of UPI who have provided support to the research team so that the research can be completed on time and the article of research results can be published in the Mimbar Journal published by LPPM of UNISBA.

\section{References}

Ardiwinata, J.S. (2014). Peran Forum PKBM dalam Meningkatkan Mutu Pengelolaan Program PAUDNI di Provinsi Jawa Tengah dan DIY. Jurnal Pedagogia. Bandung: Fakultas IImu Pendidikan Universitas Pendidikan Indonesia, Vol. 1 No. 2, Desember 2014.

Asiah, N. (2018). Analisis Manajemen PAUD Berbasis Standar Akreditasi PAUD dan PNF di Kutai Kartanegara. Jurnal Syamil. Pascasarjanan IAIN Samarinda. Vo. 6 No. 1 Tahun 2018.

Agustanico. (2017). Model Evaluasi Program Dalam Penelitian Evaluasi. Jurnal IImiah PENJAS, ISSN : 2442-3874 Vol.3 No.1, Januari 2017.

Cenny. (2018). Efektivitas Program Pendidikan Kesetaraan Paket B Dan C Oleh Pusat Kegiatan Belajar Masyarakat (PKBM) Cendikia Di Kabupaten Pangandaran. Jurnal Moderat, Volume 4, Nomor 3, Agustus 2018.

Dewi. (2014). Pengelolaan Program Pusat Kegiatan Belajar Masyarakat. Jurnal Pendidikan dan Pembelajaran Khatulistiwa, FKIP Universitas Tanjungpura, Vol. 3 No. 11 Tahun 2014.

Depdikbud. (2015). Buku Standar \& Prosedur Penyelenggaraan PKBM. Jakarta: Departemen Pendidikan Nasional.

Firmansyah, D. (2012:3). Peranan Pusat Kegiatan Belajar Masyarakat dalam Menumbuhkan Minat Baca Warga Belajar. Student E-Jurnal. Vol 1, No 1. Tahun 2012.

Hasanati, N. (2017) Pengaruh Kompetensi terhadap Komitmen Profesi pada Dosen. Jurnal Magister Psikologi UMA. Vol. 1 No. 1 Tahun 2017.

Hardjono. (2019). Model Pemberdayaan Pusat Kegiatan Belajar Masyarakat dalam Pengelolaan Program Pendidikan Kesetaraan Berbasislife Skills dan Kewirausahaan. Jurnal Non Formal Education UNNES. Vol. 1 No. 2 Tahun 2010.

Irmawati. (2017). Pusat kegaitan Belajar Masyarakat dalam Mengurangi Buta Aksara di Kabupaten Karimun. Jurnal Pendidikan dan Kebudayaan Balitbang Kemdikbud, Vol 2 No.1 Tahun 2017.

Irwan. (2016). Strategi Peningkatan Peran Pkbm Dalam Meningkatkan Kecakapan Hidup Masyarakat melalui Pendampingan Berbasis Kearifan Lokal di PKBM Provinsi Banten. Jurnal Untirta. Vol. 1. No 2 Tahun 2016. 
Irmavita. (2018). Pengelolaan Program Pendidikan Nonformal Untuk Kelompok Masyarakat Lanjut Usia. Jurnal Kolokium Pendidikan Luar Sekolah. Fakultas IImu Pendidikan Universitas Negeri Padang Sumatera Barat. Vol. 6, Nomor 1, April 2018

Kisworo, B. (2017). Implementasi Media Pembelajaran Berbasis Prinsip-Prinsip Pendidikan Orang Dewasa di PKBM Indonesia Pusaka Ngaliyan Semarang. Jurnal of Non Formal Education (JNE) UNNES. Vol. 3, No. 1 Tahun 2017.

Kurnianto, S. (2019). Menilai Keberhasilan Sistem: Validasi Model Keberhasilan Sistem Informasi Delone Dan Mclean. Jurnal Riset Akuntansi Dan Bisnis Airlangga. Vol. 4. No. 2 Tahun 2019.

Lubis, H. (2018) Paradigma Pendidikan Berbasis Masyarakat (Community Based Education). Jurnal Muqaddimah. Fakultas Agama Islam Universitas Ibnu Chaldun Jakarta. Vol. 14 No. 3 tahun 2018.

Nurleni, A. (2018). Peran Pusat Kegiatan Belajar Masyarakat (PKBM) dalam memberdayakan Masyarakat melalui Pelatihan Tata Boga. Jurnal Comm-Edu IKIP Siliwangi. Vol.1 No. 2, Tahun 2018.

Peraturan Pemerintah No.73 tahun 1991 tentang Pendidikan Luar Sekolah

Peraturan Pemerintah No. 13 Tahun 2015 tentang Standar Nasional Pendidikan, sebagai perubahan ke dua atas PP No. 19 tahun 2005.

Saepudin, A. (2015). Efektifitas Pelatihan dan Efikasi Diri dalam Meningkatkan Perilaku Berwirausaha pada Masyarakat Transisi. Jurnal Mimbar (Sosial dan Pembangunan). Bandung: P2U LPPM UNISBA, Vol. 31 No. 1. Juni 2015. ISSN: 0215-8175, Terakreditasi Dikti. SK Kemdikbud No. 040/P/2014.

Saepudin, A. (2017). The Influence of Participation in Extracurricular Activities to Learning Motivation. Jurnal Mimbar (Sosial dan Pembangunan). Bandung: P2U LPPM UNISBA, Vol. 33 No. 2. Desember2017. ISSN: 0215-8175, Terakreditasi Dikti. SK Kemdikbud No. 040/P/2014.

Saepudin, A. (2019). Conceptual Models Development of Non-Formal Education
Unit Management for Education Services Quality. Jurnal Mimbar (Sosial dan Pembangunan). Bandung: P2U LPPM UNISBA. Vol. 35 No. 2. Desember 2019. ISSN: 0215-8175, SINTA 2, 10/E/ KPT/2019 until 2024.

Septiani, M. (2015). Pengalaman Pusat Kegiatan Belajar Masyarakat (PKBM) Dalam Memfasilitasi Masyarakat Belajar Sepanjang Hayat. Jurnal IImiah Visi PPTK PAUDNI. Vol. 10, No.2, Desember 2015.

Sihombing. (2019). Pendidikan Luar Sekolah. Jakarta: Depdiknas.

Sugiyono. (2017). Metode Penelitian Pendidikan (Pendekatan Kualitatif, Kuantitatif, dan $R \& D$ ). Bandung: Alfabeta.

Suryadi. (2020). Life Skills Education Program: Is it Beneficial for the Society. Jurnal of Non Formal Education UNNES. Vol. 2 No. 2 Tahun 2020.

Sumarni. (2015). Pengembangan Model Pendidikan Karakter Berbasis Penguatan Modal Sosial Bagi Mahasiswa UIN Sunan Kalijaga. Jurnal Pembangunan Pendidikan: Fondasi Dan Aplikasi. Vol. 3, No 1, Juni 2015.

Triwiyanto, T. (2013). Standar Nasional Pendidikansebagai Indikatormutulayanan Manajemen Sekolah. Jurnal IImu Pendidikan (JIP) Universitas Negeri Malang. Vol. 19, No. 2, Desember 2013.

Undang-Undang No. 20 Tahun 2003 tentang Sistem Pendidikan Nasional.

UNESCO tahun 2005. International Eksploratif Paper. Jakarta: Depdikns.

Untadiyah (2021). Training Management of Mukena Home Industry to Improve Community's Economic Empowerment. Jurnal Empowerment; Jurnal Ilmiah Program Studi Pendidikan Luar Sekolah. Vol. 10, No. 1 Februari 2021, P-ISSN No. 2252-4738e-issn 2580-7692.

Zainal. (2019). Pusat Kegiatan Belajar Masyarakat (PKBM) Amartha Yoga Di Desa Geraokgak Bulelleng Bali. Jurnal Pendidikan Sosiologi Universitas Pendidikan Ghanesa, Vol 1 No. 1 tahun 2019. 